\title{
Guillaume Oyono Mbia's Trois prétendants...un mari:Is it a case or a question of Generational Conflict?
}

\author{
Sikiru Adeyemi Ogundokun, \\ Department of Languages and Linguitics, College of Humanities and Culture, Ikire, Osun State University, \\ Osogbo, Nigeria.
}

\begin{abstract}
Drama, poetry and prose are the three major genres of literature. They provide a functional platform where socio-cultural, political and economic conflicts are presented and debated for the purpose of reconstructing human societies for peaceful co-existence and enduring development. For adequate sharing and/or dissemination of multidimensional human experiences, feelings, imaginations, observations, findings, predictions and recommendations, the potential/capability to effectively interpret and apply literature becomes unavoidable. In this article, we try to examine Guillaume Oyono Mbia as a committed writer using his play titled: Trois prétendants...un mari as a parameter. This review is anchored on pragmatic literary method, with a strong belief that literature like other artifacts has certain essential functions to perform in rebuilding human societies through moral or behavior modification and reorientation.

The paper concludes that in reconstructing or rebuilding any human society, generational conflict is a necessary evil to cope with.

Keywords: Art, literature, conflict, culture, education, society
\end{abstract}

\section{Introduction}

Art is for the purpose of art and other things. "Literature and creativity are closely related...Literary criticism which studies the work and achievements of language in literature should be tactful, but it should be conscious too of the dignity of its calling. It is no mean thing to be an interpreter. It is delightful and proud thing to make clear the relationship between a writer's life and his work, between the traditions a writer inherits and his own individual character and temperament, between imaginative work and its social context",(Robert, Welch, 1988).

Besides the aesthetics, we hold that philosophical interest in fictional entities covers a surprisingly wide range of subject areas such as philosophy of language, ontology and metaphysics, epistemology and logic only to mention a few. Fictional entities are "principally those entities originating and defined by myths, legends, fairy tales, novels, dramas and other works of fiction", (Peter, Lamarque, 2000). A writer, whether as a playwright, a poet or a novelist is expected to embrace his time and environment very closely in his literary creation.

By society, it implies an association of people, which comprises units that integrate for living together. It concerns people that have rules of behavior such as beliefs, customs, traditions, conventions, social values and norms by which the society can change and protect the well being of the community. The family, religion, trade unions, pressure groups and professional bodies are some examples of units of a given society. In sum, society is "a particular community of people who share the same customs, laws, etc", (Hornby, A. S., 2000).

In several early stories that come from Africa, female characters always play insignificant role. If they are paraded at all, they feature as mere objects to perform marginalized functions. When navigating through the three basic genres of literature; drama, poetry and prose, we observed that a dramatist/playwright, a poet or a novelist draws from his/her experiences, observations, findings and imaginations among other things that are available at his/her disposal in enacting his/her story. "What distinguishes the novel and the story is its essential dependence on the book. The dissemination of the novel became possible only with the invention of printing... The storyteller takes what he tells from experience; his own or that reported by others. And he in turn makes it the experience of those who are listening to the tale. The novelist has isolated himself. The birthplace of the novel is the solitary individual", (Walter, Benjamin, 1969).

This view that we hold strongly about a committed writer and his/her literary creation whether as a novelist, a playwright or a poet is further consolidated by another literary giant who affirms:

... literature itself has its own purpose and determinants... never wholly autonomous, it draws its prime motives from deep within the common culture, the life experience of its producer in their time... but it never speaks for the totality of that culture", (Warner, Berthof, 1981).

As a matter of fact, literature or any work of art for that matter is not a closed entity and cannot therefore be independent or self-sufficient on its own. There is a meeting point between literature, culture and society. 
For a comprehensive understanding of our assessment of Guillaume Oyono Mbia's

Trois prétendants... un mari as a question of Generational Conflict, we would like to explain basic operational terms as they are applied in this review. First, Conflict, it is "a situation in which people, groups or countries are involved in a serious disagreement or argument. It is a situation in which there are opposing ideas, opinions, feelings or wishes; ..." (Hornby, A. S.)

Conflict is an important mechanism in story writing or telling since literature can be written or spoken words. Conflict provides the template for the story-line, plot or structure of a given story. It is what sparks off actions which different characters in a story act upon in a view to resolving it and move on with life. It is the bone of contention in a literary composition. It is possible for writers to tailor conflict along differences in sociopolitical, economic, cultural or religious ideologies which separate people in a system/society and set them against themselves.

Another vital term in our discussion is the word education. To us, education is the totality of man's experience from age zero to when he dies, which makes him an acceptable member of his community, an "omolúàbí" by contributing meaningfully through the knowledge, training, conceptual skills (in art, communication, science and/or technology) which he has acquired over the years and his undoubted moral uprightness. Hence, education is an essential tool for a mature and a happy life. It is man's "third eye", which allows him develop the expected powers of adequate reasoning and value judgment.

Again, we take time to talk about culture because the conflict we are theorizing has a serious link with culture. UNESCO defines culture as "what has shaped societies' and individuals' ways of life; while certainly rooted in ancestral values, it is also a source of dialogue, exchange, innovation and creativity, and the foundation stone of endogenous systems of solidarity, forms of expression and ways of transmitting knowledge that are as valid for meeting the challenges of tomorrow as for preserving traditions", (UNESCO, 2005). Simply put, culture is an aspect of people's identity which promotes social integration and organization among the said people. However, culture is never static, it is dynamic, hence, and it should adopt itself to the changes which come with time. In this modern world which is ruled by science and technology, an unhealthy attachment to crude and cruel culture is unacceptable as it hinders societal developments.

Ethnicity, male chauvinism, forced marriage, polygamy and ritualism are cultural practices which militate against the development of individuals, groups, institutions and the society as a whole, especially in Africa. Our writer, Guillaume Oyono Mbia is disturbed by the fact that traditional African cultures over limit the fundamental human rights of the woman in various African communities. And as a response to this ugly and wicked traditions, he wrote Trois prétendants... un mari to break the seemingly old-aged tradition of forcing a girl to marry a man she does not love.

"There is a challenge to open up to the new categories: diaries, letters, common place collections, notebooks, biographies, autobiographies as well as other media forms such as radio, television and film",(Reshma, Sookrajh, 1995). Yes, this assertion is true but happily, Oyono Mbia attempts to make women characters active in shaping lives; their own lives that of their families or to make them influence in issues which touch their society as a whole. In this essay, generational conflict is the basis of our discussion.

\section{Analysis}

Guillaume Oyono Mbia, a Cameroonian writer was born in Mvoutessi in 1939. He wrote his first play titled: Trois prétendants... un mari in 1960. The story is set in the Cameroonian environment in particular and that of Africa in general. Juliette, the heroine, is a school girl from Mvoutessi. She studies in Libamba, Cameroon. All of a sudden, Juliette's parents have concluded arrangements for her marriage and they expect her back home. This disgusting practice has indeed jeopardized the careers and lives of thousands of African girls from east to west and north to south. "This was common in instances when improvident fathers forced their daughters in marriage with rich old man. If such a girl had a lover and eloped with him, 'edje ne n'osin', (Urhobo expression for bride price), the dowry on her is refunded and damages paid", (Okumagba, 1985).

$\mathrm{Ndi}$, a farmer and stark illiterate has already paid One Hundred Thousand francs as bride price for Juliette. From Sangmelina, a civil servant is also expected to come and bid higher. Atangana and Abessolo have opposing idea as regards the education of female child.

Abessolo thinks it is a waste of resources to send a female child to school but Atangana sees it as a profitable venture which must be pursuit. Juliette disagrees with her parents on the hasty marriage arrangement when she is eventually informed about it. She frowns at the decision of her parents and argues that she is not an object to be priced and sold to the highest bidder in the game. Hence, she deserved to be consulted on matters that concern her life such as her marriage (p. 28).

As the story moves on, it is discovered that Mbia, the civil servant is somehow related to Juliette and with that he cannot marry the girl going by the tradition (pp.43-44). However, Chief Mbarga for personal interest, requests that a waiver can be given to Mbia despite the issue of lineage (pp.47-49). The waiver is 
granted and Mbia pays Two Hundred Thousand francs as bride price. Apart from the money he has paid, a long list of personal requests is also made to him as he departs (pp.54-56).

As her father joyfully informs Juliette about the progress made so far about the marriage arrangement with Mbia, she expresses her total objection to the ugly and wicked arrangement. Juliette declares that she is already in love with another person: a fellow student (pp. 61-62). This occasion of strong opposition to the decision of her parents is the hallmark of Oyono Mbia's preoccupation in Trois prétendants... un mari

Oko, Juliette's boy friend and Kouma, Juliette's cousin come into the scheme of events by planning to steal the Three Hundred Thousand francs paid by the first two suitors. The game plan is that when they steal the sum, it will pave the way for Oko and Juliette to marry each other (pp.68-72).

Towards the end, Tchetgen, a trader makes his proposal (pp.125-130) to complete the list of the three suitors. Oko disguised; dressed up like a big man, introduced by Kouma, who sang his praises and prepared a good ground for him. On his part too, Oko successfully plays the awaited big man's role. He pays the Three Hundred Thousand francs. Juliette consents in the presence of everybody and they marry.

Generational conflict is the subject-matter of this play, Trois prétendants... un mari. This is obvious in the characterization of the dramatist. The presentation of grand-parents, parents and children underscores the fact that generational shift is an issue in the story. Abessolo, Mbarga's father and Juliette's grand-father in a way, believes that sending female children to school is wastage of scarce resources. Women to him are mere objects to be seen, used and not to be heard. He is indeed an "old school" that holds strongly to the blind cultural traits. He encourages Juliette's father to collect the One Hundred Thousand francs paid by Ndi as bride price and this sets the basis for the brouhaha which paves the way for actions and in-actions in Trois prétendants... un mari.

On the contrary, the young generation believes that women should be given a fair hearing, especially on matters which concern them. For example, they must be consulted on issues of marriage since it is perceived to be a life contract. Western education has greatly helped the young generation to discover themselves and fight against social unfairness and injustice in their society.

As we can see, the psychological disposition of the old generation and the uneducated people is to continue with the blind tradition of treating female folk like ordinary object. Most often than not, mad love for material things of life accounts for unacceptable prevention of barbaric cultural practices in African societies. In the play under review, Mbarga, who discovers the parental link between Mbia and Juliette, waives the issue in a swift manner because of the material things he will gain from the suitor.

Juliette's refusal to accept the stage managed marriage plan of her parents shows her as the representative of the new generation and of course the new order in the scheme of running the modern society. Juliette symbolizes the real African woman who is blessed with knowledge, wisdom and understanding to cope with the man dominated society where she finds herself. Because she can think for herself, Juliette revolts against socio-cultural injustice which kicks her on her face. Juliette takes up her father by asking these questions: "Le Quoi? Je suis donc à vendre? Pourquoi faut-il que vous essayiez de me donner au plus offrant? Est-ce qu'on ne peut pas me consulter pour un mariage qui me concerne ?» (p. 45) [What? I am therefore for sale? How could you give me out like a mere offer? Can't someone seek my consent in a marriage that concerns me?]

These questions x-ray the different generations of characters that are involved in the actions in the play, Trois prétendants... un mari. The questions again prepare the readers' mind for what they should expect. In fact, with these questions, we understand also that Juliette stands in for the educated African women who want to be treated as a dignified human being. Juliette is a symbol of woman emancipation with the quest for equality, fair treatment of both men and women for a peaceful co-existence and human advancement in general.

To the young generation, love is not all about money or material gain. It is a matter of emotion/feeling and perhaps passion. Let consider the discussion between Juliette and her mother, Makrita on page 62.

Juliette: Est-ce que l'argent est une preuve d'amour?

[Is money the proof of love?]

Makrita: Bien sûr que oui! Tu ne le savais pas ?

[Yes, of course! You didn't know?]

Julitte: Je vous a dit que mon fiancé n'a pas d'argent, et pourtant je suis sûre qu'il m'aime.

[I have told you my fiancé does not have money but I am sure he loves me].

This extract above shows that the old generation is controlled by materialism. Meanwhile the young generation is more rational because people of this generation do not see money as everything.

As Juliette's parents refuse to listen to her own side of the story and her feelings, she discusses the idea of stealing the money paid by the first two suitors with Oko and Kouma. This action further stresses that the young generation is an embodiment of fresh functional ideas and it is a generation which is bent on searching for workable solutions to problems which confront them by looking inward. This opposes the conservative idealistic posture of the old generation which depends principally on external help and solution to their domestic 
problems. For instance, the old generation calls in Sanga-Titi, a witch-doctor to come help in unmasking the misery behind the stolen money.

Characters used in Guillaume Oyono Mbia's Trois prétendants... un mari, are chosen from the three main social stratifications found in human societies. The ruling elites represented by Marga, the middle class, which Mbia symbolizes and the masses, the lower class represented by Ndi. The play, Trois prétendants... un mari, can be described as a Marxist drama. It is a people's piece because it allows the young, the old, the male and the female, the literate and the illiterate to display their lot. Oko and Kouma join women in their struggle for liberation in a male-dominated African society. And of course, the marriage between Oko and Juliette is a mark of hope for impeding victory in the said struggle

This issue of forced marriage is a common practice in African societies. Apart from the case of Juliette in Guillaume Oyono Mbia's Trois prétendants... un mari, one also recalls Zénabou, the heroin in Mbuko Lynn's Chaque Chose En Son Temps, where the young girl was forced to leave school only to be married to a rich Elhadj, who was as old as the girl's father, with many wives and several children.

However, it is pretty enough for Juilette, she defeats her parents in the game and marries Oko, the man her heart desires; it was not so for Zénabou perhaps because of her level of education and her milieu. Education helps Juliette. As a higher school student, she knows her onions and stands tall to fight against the socio-cultural injustice and unfair treatment directed at not only her but also the rest of women in Cameroon and elsewhere in Africa. By liberating the womenfolk as it were, she has contributed meaningfully to her society. Having acquired a skill as a trained nurse at the end too, Zénabou in Mbuko Lynn's Chaque Chose En Son Temps also contributes strongly to her society.

The language used in the play, Guillaume Oyono Mbia's Trois prétendants... un mari is appropriate and balanced looking at the character traits and the dispositions of those involved in the story and the significance of their role. "No poet, no artist of any art, has his complete meaning alone. His significance, his appreciation is the appreciation of his relation to the dead poets and artists. You cannot value him alone; you must set him, for contrast and comparison, among the dead. I mean this as a principle of aesthetic, not merely historical, criticism. The necessity that he shall conform, that he shall cohere, is not one sided; what happens when a new work of art is created is something that happens simultaneously to all the works of art which preceded it", (T. S. Eliot, 1932). In Guillaume Oyono Mbia's Trois prétendants... un mari, the use of language reflects the social status of the characters. The choice of words and expressions of Juliette, Oko and Kouma mark them out as well educated fellows. The diction of these three characters also shows the playwright's proficient mastery of the French language.

\section{Conclusion}

Apart from unacceptable restrictions imposed on women through religious injunctions, Africa culture itself is a thorn on the flesh of women. An ugly social norm wide spread in Africa is the parental intrusion into marriage of their children especially daughters. The parents, often motivated by interest contrary to those of their children, drag their offspring away from genuine love and sacrifice their happiness on the altar of greed and social stratification, ethnicity, political or religious differences and local taboos. The story, Guillaume Oyono Mbia's Trois prétendants... un mari, is both a case and a question of Generational conflict. As a case, it shows a particular situation or example of a practice in African societies and as a question, the story is set to test the Africans' knowledge or ability to handle or solve an issue/a challenge, which confronts them looking inward; that is, by themselves. In short, we have attempted to explore principally the theme of generational conflict to explain societal shift in African societies. Featuring the theme of generational conflict, one can perceive that Guillaume Oyono Mbia is a Marxist or a post-modern feminist.

For dignity, well deserved recognition and to contribute positively to the socio-economic and political development of their various nations, the education of female children is important. Education is power and key to success anywhere under the sun. Hence, solving the brouhaha which emanates from generational conflict is the panacea to the peaceful co-existence and advancement of African societies and the world at large. We, at this juncture, proudly submit that some African male writers of French expression are "male feminists" because they present their female characters in a positive light: as good, intelligent, rational and determined. This is exactly what Guillaume Oyono Mbia does in his first play, Trois prétendants... un mari.

\section{References}

[1] Ade, Ojo and Oke, O. (eds 2001). Themes in African Literature in French, Ibadan, Spectrum books Ltd.

[2] Adebayo, Aduke (2010). The Nature and Function of Literature: The Comparatist's Perspective. An Inaugural Lecture, University of Ibadan.

[3] Amuta, C. "Towards Sociology of African Literature” in Essays on Literature and Society. Oguta, Zimpan Publishers, 1987.

[4] Ayu, I. "Creativity and Protest in popular culture: The political Music of Fela Anikulapo Kuti" in Essays in popular Struggle. Oguta, Zimpan Publishers, 1986

[5] Barry, P. (1995). Beginning Theory. Manchester University Press.

[6] Benjamin, Walter. "The Story Tellers". In Illuminations. Hannah, A. (eds). New York; Schochen, 1969. 
[7] Berthof, Warner (1981). The Ferment of Realism. Cambridge, Cambridge University Press

[8] Caine, Barbara. “A South African Revolutionary, but a lady of British Empire": Helen Joseph and the Anti-Apartheid Movement in Journal of Southern African Studies, Vol. 34. Routledge, 2006.

[9] Davies, Joanne. "South African and Constructive Engagement: Lesson Learned?" In Journal of Southern African Studies, Vol. 34, Routledge, 2008.

[10] Eliot, T. S. "Tradition and the Individual Talent", in Selected Essays, London: Faber \& Faber, 1988.

[11] Hornby, A. S. (2000). Oxford Advanced Learner's Dictionary of Current English. Oxford, Oxford University Press.

[12] Lamarque, Peter. "Fictional Entities". In Concise Routledge Encyclopedia of Philosophy; New York \& London. Routledge, 2000.

[13] Layiwola, Dele (2010). A Place where three roads meet: Literature, Culture and Society. An Inaugural Lecture, Ibadan, University of Ibadan.

[14] Mbia, G. Oyono (1964). Trois prétendants... un mari, Yaoundé, Editions CLE

[15] Ogundokun, Sikiru, A. «Sociolinguistic Resources in Mbuko Lynn's Chaque Chose En Son Temps » in Journal of Humanities And Social Science, Vol.8, Issue 1;2013.

[16] Okumagba, M. P. A. (1985). A Short History of Urhobo. Lagos: Kris and Pat, Nigeria.

[17] Pelkhanov, G. “Art and Social Life”, in Selected Philosophical Works. Vol. v; Moscow: Progress Publishers, 1981

[18] Reshma, Sookrajh. "Towards Reconstructing a Curriculum for Secondary Schools", in Alternation 2, 1995.

[19] Tyson, I. (1991). Critical Theory Today. New York. Garland Publishing Press.

[20] UNESCO. "Education and Culture in Africa's Quest for Development", a UNESCO's Preliminary Contribution to the Conference of Ministers of Education of the African Union, Algiers, Algeria, 8-11 April, 2005.

[21] Welch, R. and Suheil, B. Bushrui, (eds. 1988). Literature and the Art of Creation, Gerrards Cross: Colin Smythe. 